Herbst treatment in class II malocclusion.

4. Sidlauskas A. (2005), The effects of the Twinblock appliance treatment on the skeletal and dentolaveolar changes in Class II Division 1 malocclusion. Medicina (Kaunas). 41(5), 392-400.

5. Khoja A., Fida M. and Shaikh A. (2016), Cephalometric evaluation of the effects of the Twin Block appliance in subjects with Class II, Division 1 malocclusion amongst different cervical vertebral maturation stages. Dental press journal of orthodontics. 2173-84

6. Moyers R.E., Riolo M.L., Guire K.E., et al. (1980), Differential diagnosis of Class II malocclusions: Part 1. Facial types associated with Class II malocclusions. American journal of orthodontics. 78(5), 477-494.

\title{
MẤT PROTEIN QUA RUỘT - MộT BIẾN CHỨNG NẶNG CỦA NHIỄM GIUN MÓC: BÁO CÁO CA BÊNNH
}

\section{TÓM TẮT}

Mục tiêu: Mô tả đặc điểm lâm sàng, cận lâm sàng và kết quả điều trị trường hợp nhiễm giun móc có biến chứng giảm protein máu nặng. Đối tượng và phương pháp: Báo cáo ca bệnh có biến chứng nặng của giun móc tai khoa Cấp cứu và Chống đôc, Bểnh viện Nhi Trung ương. Kết quả: Trẻ gái 20 tháng tuổi, dẩn tộc Mường nhấp viên vì li bì và tiêu chảy. Xét nghiệm cho thấy trẻ thiếu máu rất nặng, bạch câuu ưa acid tăng cao và protein máu giảm nặng. Bệnh nhân được điều trị tình trạng cấp cứu và xác định những căn nguyên gây giảm protein máu; loai trừ bênh lý: sựy dinh dưỡng, gan và thận,... Dựa vào yếu tố dịch tê̂ và các triêu chứng gợi ý, chúng tôi đã chỉ định xét nghiệm tìm kí sinh trùng trong đó có tìm trứng giun móc đồng thời định lượng nồng độ alpha 1 antitrypsin (A1AT) trong phân. Kết quả mẫu phân có rất nhiều trứng giun móc $(+++)$ và tăng nồng độ $A 1 A T(106,2$ $\mathrm{mg} / \mathrm{dL}$ ). Chẩn đoán xác định là mất protein qua ruột (PLE) do nhiễm giun móc. Điều trị bằng albendazol trong 3 ngày. Sau 16 ngày chẩn đoán và điêu trị, bệnh nhân đại tiện bình thường, hết phù, protein máu không giảm lại và được xuất viện. Kết luận: Mặc dù nhiễm giun móc là bệnh tương đối phổ biến ở các nước đang phát triển nhưng biến chứng năng như mất protein qua ruột thường hiếm gặp vì vậy cần được chẩn đoán và điều trị kịp thời để tránh tình trạng nguy kịch đến tính mạng.

Tư khóa: Giun móc, mất protein qua ruột, trẻ em

\section{SUMMARY}

PROTEIN - LOSING ENTEROPATHY - A SEVERE COMPLICATION OF HOOKWORM INFECTION: A CASE REPORT

Objectives: Describe clinical, investigations and treatment results of hookworm infections with severe hypoproteinemia. Subjects and methods: Report a

\footnotetext{
*Bệnh viện Nhi Trung ương

Chiu trách nhiệm chính: Lê Ngọc Duy

Email: Drduy2411@gmail.com

Ngày nhận bài: 13.9.2021

Ngày phản biện khoa học: 11.11.2021

Ngày duyệt bài: 18.11.2021
}

\section{Lê Ngọc Duy*, Trần Duy Mạnh*, Lương Thị Liên*, Đặng Thúy Hà*}

case of severe complications of hookworm at the Department of Emergency and Poison Control, National Children's Hospital. Results: A 20-month-old girl from the Muong ethnic was admitted because of lethargy and diarrhea. Initial tests showed that the child had severe anemia, with elevated eosinophils and severe hypoproteinemia. The patient was treated for the emergency condition and investigated common causes of hypoproteinemia. Patients were excluded: malnutrition, liver and kidney diseases,... Based on epidemiological factors and symptoms, we prescribed tests for parasites including worm eggs and quantified alpha 1 antitrypsin (A1AT) level in the stool. The child's stool showed a lot of hookworm eggs $(+++)$ and increased A1AT concentration (106.2 mg/dL). The patient was confirmed with protein-losing enteropathy (PLE) due to hookworm infection and was treated with albendazole for 3 days. After 16 days of diagnosis and treatment, the patient had normal bowel movements, no edema, no reduction in serum protein and was discharged. Conclusion: Although hookworm infection is a common disease in developing countries, severe complications of hookworm such as proteinlosing enteropathy are rare, so prompt diagnosis and treatment is required to avoid life-threatening.

Keywords: Hookworm, protein-losing enteropathy, child

\section{I. ĐĂT VẤN ĐỀ}

Giun móc là một trong những bệnh giun lây truyền qua đất, khá phổ biến ở các nước có khí hậu nhiệt đới và cận nhiệt đới. Theo Tổ chức Y tể thế giới ước tính trên thế giới có 1,5 tỷ người nhiễm giun móc/mỏ. Ở Việt Nam, bệnh giun móc đứng hàng thứ hai sau bệnh giun đũa, qua các kết quả điêu tra, tỉ lệ nhiễm giun móc ở Việt Nam từ $3-80 \%$ tùy theo tính chất nghề nghiệp, tập quán canh tác, điều kiên vê sinh và tính chất thổ nhưỡng ở từng vùng. Ở miền Bắc tỉ lệ nhiễm ở đồng bằng từ 30 - 60\%, vùng trung du 64\% và vùng núi $61 \%$ [1].

Vòng đời của giun móc từ giai đoạn trứng trong phân được bài xuất ra ngoài, gặp điêuu kiện thuận lợi nở thành âu trùng trong 1-2 ngày, khi 
phát triển thành ấu trùng hình chỉ có thể lây nhiễm cho người qua da gây các bệnh cảnh viêm da hoặc viêm phổi nhẹ. Âu trùng trưởng thành ở tá tràng và ruô̂t non, chúng bám vào thành ruột và gây mất máu mạn tính ở vật chủ. Mỗi ngày một con giun móc hút khoảng $0,04-0,16 \mathrm{ml}$ máu. Hậu quả của nhiễm giun móc mạn tính là thiếu máu hồng cầu nhỏ nhược sắc mức độ trung bình hoặc nặng, những trường hợp nặng có thể gây ra chậm phát triển thế chất và tâm thần, phù do giảm protein, albumin máu. Để chẩn đoán xác định nhiễm giun móc cần soi phân tìm trứng giun móc [0],[2].

Giảm protein máu có thể do giảm sản xuất (xơ gan, suy dinh dưỡng,...) hoặc mất qua thận, qua ruột hoặc mất sang khoang thứ ba. PLE đặc trưng bởi tình trạng mất protein trong đó có albumin vượt quá khả năng tổng hợp dẫn đến giảm protein và albumin máu. PLE có thể do tăng áp lực hệ mạch huyết ruột hoặc do các bệnh lý làm viêm loét niêm mạc ruột hoặc không. Chẩn đoán nguyên nhân gây PLEE có ý nghĩa quyết định đến điêuu trị và tiên lượng, nếu không bệnh nhân sẽ tiếp tục mất protein dẫn đến phù nhiều, suy hô hấp (do tràn dịch màng phổi, cổ chướng), suy giảm miễn dịch, nhiễm trùng nặng (do mất Ig và bạch cầu lympho) và có thể tử vong [3].

Vì tính chất ít gặp, nặng và khó chẩn đoán, dễ bị bỏ sót chúng tôi xin báo cáo một trường hợp trẻ nữ 20 tháng tuổi vào viện vì tiêu chảy, phù toàn thân, giảm protein máu nặng được chúng tôi chẩn đoán xác định mất protein qua ruột do nhiễm giun móc và điều trị thành công bằng albendazol.

\section{GIỚI THIỆU CA BỆNH}

Bệnh nhẩn nữ 20 tháng tuổi dân tộc Mường là con lần 1 , đẻ thường, đủ tháng, cân nặng lúc sinh $3,0 \mathrm{~kg}$, hiện tại trẻ $9 \mathrm{~kg}$ (>-2SD theo WHO), trẻ chưa mắc bệnh lý gì trước đây. Trước vào viện 4 ngày bố mẹ phát hiện trẻ phù toàn thân, bụng chướng tăng dân, da xanh, không sốt, tré được khám tại bệnh viện đa khoa huyện Phù Yên, tỉnh Sơn La và được chuyển đến Bệnh viện Nhi Trung ương ngay trong ngày. Tại khoa CC$\mathrm{C}$, toàn trạng trẻ ổn định, triệu chứng nổi bật là da xanh niêm mạc rất nhợt, phù toàn thân và bụng chướng hơi nhiều, trẻ đại tiện phân lỏng ngày 3-4 lần, phân đen. Xét nghiệm cơ bản thâyy có tình trạng thiếu máu rất nặng hemoglobin $(42 \mathrm{~g} / \mathrm{L})$ và giảm albumin máu nặng $(17,8 \mathrm{~g} / \mathrm{L})$, protein máu toàn phần là $46,6 \mathrm{~g} / \mathrm{L}$, fibrinogen là $1,1 \mathrm{~g} / \mathrm{L}$, mõ máu bình thường (triglycerid
2,52mmol/L, cholesterol 2,14mmol/L). Bệnh nhân được điều trị cấp cứu bằng truyền khối hồng cầu và truyền albumin $20 \%$ đồng thời nhanh chóng được làm các xét nghiệm tìm nguyên nhân thiếu máu và giảm albumin máu.

Công thức máu toàn phần cho thây có tình trạng thiếu máu rất nặng hồng cầu nhỏ nhược sắc (MCV 69,7 femtolit, MCH 21,5 picogam) và tăng bạch cầu máu với số lượng bạch câu là 28 $\mathrm{G} / \mathrm{L}$, cồng thức bạch cầu có tăng bạch cầu ưa acid $(34,7 \%)$. Các xét nghiệm tìm nguyên nhân thiếu máu cho thấy trẻ có tình trạng thiếu sắt (sắt huyết thanh $1,2 \mathrm{micromol} / \mathrm{L}$, ferritin $9,7 \mathrm{ng} / \mathrm{ml})$, không tìm thấy máu trong phân. Từ công thức bạch cầu gợi ý trẻ có thể nhiễm kí sinh trùng vì vậy bệnh nhân đã được làm xét nghiệm Elisa tìm kí sinh trùng nhưng không phát hiện được trong huyết thanh, nhưng xét nghiệm soi phân tìm trứng giun móc phát hiện thấy rất nhiều trứng giun móc $(+++)$.

Albumin máu giảm nặng không phù hợp với tình trạng dinh dưỡng của trẻ, các xét nghiệm men gan trong giới hạn bình thường, không có suy chức năng gan, không có protein niệu trong tổng phân tích nước tiểu. Trong khi đó lẩm sàng bệnh nhân có tiêu chảy, bụng chướng hơi nhiều, chụp cắt lớp vi tính ố bụng thấy giãn dạ dày, ruột non và khung đại tràng, gợi ý nguyên nhân mất protein là từ đường tiêu hóa. Định lượng nồng độ alpha -1 - antritrypsin trong phân cho kết quả là $106,2 \mathrm{mg} / \mathrm{dl}$ (>100mg/dL) ủng hộ cho chẩn đoán này.

Chúng tôi chẩn đoán xác định bệnh nhân bị thiếu máu rất nặng - mất protein qua ruột do nhiễm giun móc. Sau khi xử trí tình trạng cấp cứu, bệnh nhân được điều trị giun móc bằng albendazol $200 \mathrm{mg} \times 1$ viên/ngày trong 3 ngày. Sau 16 ngày nhập viện chẩn đoán và điêu trị bệnh nhân hết phù, protein máu không giảm lại, ăn tốt, đại tiện bình thường và trẻ được xuất viện.

\section{BÀN LUÂ̂N}

Tại Việt Nam, theo các điều tra cho thấy tỉ lệ nhiễm giun truyền qua đất trong cộng đồng vẫn còn cao nhưng do không có diễn biến rầm rộ và không có các triệu chứng rõ rệt ở giai đoạn đâuu nên chưa được người dân quan tâm đúng mức. Tỉ lệ nhiễm giun chung của cả nước vào khoảng $30 \%$, cao nhất là giun đũa, đứng hàng thứ hai là giun móc/mỏ. Cá biệt, ở những cộng đồng dân tộc thiểu số, tỉ lệ nhiễm giun móc/mó chiếm tỉ lệ rất cao (trên $90 \%$ ) [1].

Triệu chứng lâm sàng của nhiễm kí sinh trùng thường không đặc hiệu, bệnh nhân thường đên 
với biểu hiện của thiếu máu, suy dinh dưỡng, rối loạn tiêu hóa có thể là táo bón, tiêu chảy, bụng chướng, đau bụng, có thể sốt, công thức máu ngoại vi thấy bạch câu ái toan tăng cao. Thiếu máu là biểu hiện lâm sàng chính của nhiếm giun móc ở người. Theo nghiên cứu của Nguyễn Văn Đề trên 478 người bị nhiễm giun móc/mỏ tuổi từ 1 - 70 tuổi thấy hồng câu giảm ở $74,6 \%$ bênh nhân, Hemoglobin giảm ở người nhiễm giun nhe là $51,3 \%$ với $\mathrm{Hb}$ trung bình là $9,7 \mathrm{~g} / \mathrm{dL}$, ở người nhiễm giun móc/mỏ nặng là $91 \%$ với $\mathrm{Hb}$ trung bình là $8,8 \mathrm{~g} / \mathrm{dL}$, bach cầu ái toan tăng ở $76,1 \%$ bệnh nhân. Các yểu tố dịch tễ như dân tộc thiểu sổ, điều kiện vệ sinh kém, đi chân đất, không được tẩy giun định kì,... hay các triệu chứng kể trên chỉ là yếu tố gợi ý đến nhiễm kí sinh trùng. Để khẳng định chẩn đoán cần có xét nghiệm cận lâm sàng, như trong nhiễm giun móc/mỏ phải tìm được trứng giun trong phân. Bác sĩ lâm sàng cần có kinh nghiệm để chỉ định xét nghiệm chẩn đoán phù hợp như xét nghiệm trực tiếp tìm kí sinh trùng (trứng, âuu trùng, con trưởng thành) hoặc các xét nghiệm gián tiếp như phản ứng miển dịch huỳnh quang [1].

Mất protein qua ruột do kí sinh trùng còn ít được báo cáo, chủ yếu các báo cáo đề cập tới trùng roi và giun lươn. PLE nên được nghĩ đến ở những bệnh nhân có nồng độ protein huyết thanh thẩp mà đã loại trừ các nguyên nhân gây giảm protein máu khác như suy dinh dưỡng, bênh lý gan hay mất qua thận. Thông thường, hẩu hết các protein đi vào ruột sẽ bị phân giải thành các axit amin và được tái hấp thu. Trong trường hợp đường tiêu hóa bị tổn thương viêm do kí sinh trùng, tính thấm của niêm mạc tăng lên, dẫn đến rò rỉ quá nhiều protein huyết thanh vào ruột cùng với tình trạng tái hấp thu kém dẫn đến giảm protein máu. Triệu chứng lâm sàng của mất protein qua ruột phụ thuộc vào căn nguyên, triệu chứng chung phổ biến nhất là phù ngoại vi do giảm áp lực thẩm thấu huyết thanh, đôi khi bệnh nhân có thể thấy khó thở do tràn dịch màng phổi hoặc cổ chướng. Tình trạng này có thể làm mất các globulin miễn dịch và tế bào lympho, gây suy giảm miễn dịch dẫn đến bệnh nhân có thể bị nhiểm trùng cơ hội [2].

Để chẩn đoán xác định PLE cần dựa vào xét nghiệm. Trước đây đo độ thanh thải các đại phân tử được đánh dấu bẳng đồng vị phóng xạ như $51 \mathrm{Cr}$ - Albumin, 125 -I-Albumin hay $99 \mathrm{mTC}-$ Transferrin được sử dụng chẩn đoán PLE tuy nhiên giá thành đắt, kĩ thuật phức tạp, liên quan tới đồng vị phóng xạ và cần thu thập phân trong nhiều ngày. Hiện tại, phương pháp đo độ thanh thải đường ruột alpha-1-antitrypsin (A1AT) khắc phục được những nhược điểm trên đã trở thành xét nghiềm chính và phổ biến nhất được thực hiện để chẩn đoán PLE. A1AT là một glycoprotein được tổng hợp bởi gan có trọng lượng phân tử cao hơn albumin, được bài tiết trực tiếp vào phân và không bị phân hủy bởi các men trong ruột. Độ thanh thải của nó được tính bằng cách thu thập phân trong 24 giờ và đo A1AT trong huyết thanh và phân. Tuy vậy đo dộ thanh thải $\mathrm{A} 1 \mathrm{AT}$ vẫn cần thu thập phẩn trong vòng 24 giờ, khá bất tiện nhất là ở trẻ nhỏ [8].

Phương pháp định lượng nồng độ A1AT trong mẫu phân bất kì giảm bớt sự bất tiện của xét nghiệm đo độ thanh thải A1AT. Các tác giả Crossley $\mathrm{JR}$ và Elliott $\mathrm{RB}$ cho rằng nông độ của A1AT là một chỉ số tin cậy đánh giá mất protein qua ruột, giúp sàng lọc bệnh lý này và theo dõi quá trình đáp ứng điều trị. Bình thường nồng độ của A1AT trong phân là $\leq 54 \mathrm{mg} / \mathrm{dL}$, nếu $\geq 100$ $\mathrm{mg} / \mathrm{dL}$ là có giá trị trong chẩn đoán PLE [7].

Các báo cáo về mất protein qua ruột liên quan đến giun móc/mỏ còn nhỏ lẻ. Năm 1971, Areekul và cộng sự sử dụng $51 \mathrm{Cr}$-Albumin để nghiên cứu PLE ở những bệnh nhân nhiễm giun móc có lượng trứng giun trong phân từ 1200 20000 /gram phân thây rằng lượng $51 \mathrm{Cr}$-Albumin trong phân tỉ lệ thuận với số lượng trứng giun và tỉ lệ nghịch với lượng albumin trong máu [5]. Nghiên cứu của Mahesh C. Gupta và cộng sự đánh giá tình trạng mất protein qua ruột bằng phương pháp đo độ thanh thải của $51 \mathrm{Cr}$-Albumin ở 11 bệnh nhân mắc giun móc/mỏ mức độ nhẹ trong độ tuổi từ $15-60$ tuổi thãy rằng chỉ có 1 bệnh nhân có tăng mất protein qua ruột và bệnh nhân đó cũng là người có nhiều trứng giun trong phân nhất. Trong nghiên cứu của mình, Blackman và cộng sự sử dụng phương pháp đo độ thanh thải của 131I-Albumin thấy rằng cả 17 bệnh nhân nhiễm giun móc mức độ nặng đều thấy tăng mất protein qua ruột, gấp khoảng 2 lần so với bình thường [6]. Kết quả ở những nghiên cứu này cho thấy rằng PLE thường xảy ra ở những bệnh nhân mắc giun móc/mỏ mức độ nặng. Bệnh nhân trong báo cáo của chúng tôi cũ̃ng mắc giun móc/mỏ mức độ nặng.

Điều trị PLE do nhiễm giun móc bằng cách điều trị giun móc, tư vấn chế độ dinh dương phù hợp[2]. Các thuốc điều trị giun móc gồm 2 nhóm benzimidazol (mebendazol và albendazol) và nhóm pyrimidin (pyrantel pamoat). Tất cả đều hiệu quả trong điều trị, dùng liều duy nhất trong trường hợp nhe, nếu mức độ nặng dùng trong 3 ngày liên tiếp. Ớ trẻ 1 tuổi, WHO khuyến cáo liều 
của albendazol bằng một nửa liều trẻ lớn hơn và người trưởng thành. Chúng tôi sử dụng albendazol với liều của trẻ 1 tuổi trong 3 ngày liên tiếp và thấy đáp ứng tốt với điêu trị.

\section{KẾT LUẬN}

Mất protein qua ruột do giun móc là một biến chứng nặng, ít gặp và dễ bị bỏ sót. Triệu chứng nhiễm kí sinh trùng nói chung và giun móc nói riêng thường không đặc hiệu, vì vậy bác sĩ lâm sàng cần phải có kinh nghiệm để nghĩ tới và chỉ định xét nghiệm chẩn đoán phù hợp.

\section{TÀI LIÊU THAM KHẢO}

1. Nguyễn Văn Đề (2013). Giun sán y học. Ký sinh trùng trong lâm sàng, Nhà xuất bản y học, Hà Nội, 1, 37-42.

2. Hotez P J, Brooker S, Bethony J $M$, et al (2004). "Hookworm infection". N Engl J Med, 351 (8), 799-807.
3. Gounden V, Vashisht $R$, Jialal I (2021). Hypoalbuminemia, StatPearls PublishingCopyright (C) 2021, StatPearls Publishing LLC.

4. Gupta M C, Basu A K, Tandon B N (1974). "Gastrointestinal protein loss in hookworm and roundworm infections". Am J Clin Nutr, 27 (12), 1386-1389.

5. Areekul $S$, Devakul $K$, Chantachum $Y$, et al (1971). "Gastro-intestinal protein loss in patients with hookworm infection". J Med Assoc Thai, 54 (1), 28-33.

6. Blackman V, Marsden P D, Banwell J, et al (1965). "Albmin metabolism in hookwworm anemias". Trans R Soc Trop Med Hyg, 59 472-482.

7. Crossley J R, Elliott R B (1977). "Simple method for diagnosing protein-losing enteropathies". Br Med J, 1 (6058), 428-429.

8. Florent $C_{\text {, }}$ L'Hirondel $C_{\text {, }}$ Desmazures $C_{\text {, }}$ et al (1981). "Intestinal clearance of alpha 1antitrypsin. A sensitive method for the detection of protein-losing enteropathy". Gastroenterology, 81 (4), 777-780.

\section{TÌNH TRANG DINH DƯỠNG TRẺ 3-5 TUỔI VÀ MộT SỐ YẾU TỐ LIÊN QUAN ĐẾN SUY DINH DƯỡNG THẤP CÒI TẠI MộT SỐ XÃ, TỈNH THANH HÓA NĂM 2017}

\section{TÓM TẮT}

Muc tiêu: Mô tả tình trang dinh dưỡng trẻ 3-5 tuổi và một số yếu tố liên quan đến suy dinh dưỡng thấp còi tại một số xã, tỉnh thanh hóa năm 2017. Phương pháp: Nghiên cứu mô tả cắt ngang trên 1522 trẻ 3- 5 tuổi tại 6 xã, tỉnh Thanh Hóa, nhằm mô tả tình trạng dinh dưỡng và một số yếu tố liên quan đến suy dinh dưỡng thấp còi của trẻ em 3-5 tuổi. Trẻ được cân, đo chiêu cao bằng phương pháp nhân trắc hợc, phỏng vấn các bà me bằng bộ câu hỏi được thiết kể sẵn. Kết quả: Kết quả nghiên cứu cho thẩy tỷ lệ suy dinh dưỡng thể nhe cân là 9,6\%; thể thấp còi là $14,5 \%$ và thể gây còm là $1,2 \%$, Thửa cân, béo phì là $2,9 \%$. Một số yếu tố liên quan đễn tình trạng suy dinh dưỡng của trẻ bao gồm cân nặng sở sinh dưới 2500gram; mẹ có trình độ học vấn dưới trung học phổ thông; số con trong gia đình từ 3 con trở lên. Kết luận: Tỷ lệ suy dinh dưỡng trẻ em 3-5 tuổi tại 6 xã, tỉnh Thanh Hóa đứng đầu là suy dinh dưỡng thể thấp còi, cân nặng sơ sinh dưới 2500 gram, mẹ có trình độ học vấn dưới trung học phổ thông, số con trong gia đỉnh từ 3 con trở lên là các yếu tố nguy cơ của bệnh này.

\footnotetext{
${ }^{1}$ Trường Đại học Y Dược Hải Phòng

2Viện Dinh dưỡng

Chịu trách nhiệm chính: Phạm Thị Thư

Email: ptthu@hpmu.edu.vn

Ngày nhận bài: 14.9.2021

Ngày phản biện khoa học: 11.11.2021

Ngày duyệt bài: 19.11.2021
}

Phạm Thị Thư ${ }^{1}$, Trương Tuyết Mai ${ }^{2}$, Nguyễn Ngọc Sáng ${ }^{2}$, Trần Thị Thu Trang ${ }^{2}$

Tư Khóa: Suy dinh dương, trẻ em, yếu tố liên quan đến suy dinh dưỡng.

\section{SUMMARY \\ NUTRITIONAL STATUS AND SOME RELATED FACTORS TO STUNTING \\ MALNUTRITION AMONG CHILDREN 3-5 \\ YEARS OLD IN SOME COMMUNES OF THANH HOA PROVINCE IN 2017}

Objectives: Describe nutritional status and some related factors to stunting malnutrition among children 3-5 years old in some communes of thanh hoa province in 2017. Method: A cross-sectional study was conducted on 1522 children 3-5 years old in six communes of Thanh Hoa province to describe nutritional status and some related factors to stunting malnutrition among children 3-5 years old. Children were measured weight, height by the anthropometric method, interviewed mothers with pre-designed questionnaires. Results: the prevalence of underweight was $9,6 \%$, stunting was $14,5 \%$ and wasting was $1,2 \%$, overweight, obese was $2,9 \%$. Some factors related to stunting malnutrition of the child including birth weight below 2500 gram; mother has an education level below high school, the number of children in the family is 3 or more. Conclusion: The prevalence of malnutrition among children 3-5 years old in 6 communes, Thanh Hoa province is ranked first by stunting, birth weight less than 2500 grams, mothers with less than high school education, 